\title{
THE
}

\section{Synthesis and characterization of mixed-ligand diimine-piperonal thiosemicarbazone complexes of ruthenium(II): Biophysical investigations and biological evaluation as anticancer and antibacterial agents}

Floyd A. Beckford

Jeffrey Thessing

Michael Shaloski Jr.

P. Canisius Mbarushimana

Follow this and additional works at: https://digitalcommons.uri.edu/bps_facpubs Alyssa Brock

This is a pre-publication author manuscript of the final, published article.

Creative Commons License

(c) (i) (9) age for additional authors

This work is licensed under a Creative Commons Attribution-Noncommercial-No Derivative Works 4.0 License.

\section{Citation/Publisher Attribution}

Beckford, F. A., Thessing, J., Shaloski Jr., M., Mbarushimana, P. C., Brock, A., Didion, J., Woods, J.,...Seeram, N. P. (2011). Synthesis and characterization of mixed-ligand diimine-piperonal thiosemicarbazone complexes of ruthenium(II): Biophysical investigations and biological evaluation as anticancer and antibacterial agents. Journal of Molecular Structure, 992(1-3), 39-47. doi: 10.1016/ j.molstruc.2011.02.029 Available at: https://doi.org/10.1016/j.molstruc.2011.02.029

This Article is brought to you for free and open access by the Biomedical and Pharmaceutical Sciences at DigitalCommons@URI. It has been accepted for inclusion in Biomedical and Pharmaceutical Sciences Faculty Publications by an authorized administrator of DigitalCommons@URI. For more information, please contact digitalcommons-group@uri.edu. 


\section{Authors}

Floyd A. Beckford, Jeffrey Thessing, Michael Shaloski Jr., P. Canisius Mbarushimana, Alyssa Brock, Jacob Didion, Jason Woods, Antonio Gonzalez-Sarrías, and Navindra P. Seeram 


\title{
Synthesis and characterization of mixed-ligand diimine- piperonal thiosemicarbazone complexes of ruthenium(II): Biophysical investigations and biological evaluation as anticancer and antibacterial agents
}

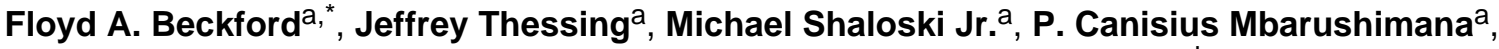 \\ Alyssa Brock ${ }^{\mathrm{a}}$, Jacob Didion ${ }^{\mathrm{a}}$, Jason Woods ${ }^{\mathrm{a}}$, Antonio Gonzalez-Sarrías ${ }^{\mathrm{b}}$, and Navindra P. \\ Seeram ${ }^{b}$ \\ aScience Division, Lyon College, Batesville, AR 72501, USA \\ bDepartment of Biomedical and Pharmaceutical Sciences, College of Pharmacy, University of \\ Rhode Island, Kingston, RI 02881, USA
}

\begin{abstract}
We have used a novel microwave-assisted method developed in our laboratories to synthesize a series of ruthenium-thiosemicarbazone complexes. The new thiosemicarbazone ligands are derived from benzo[ $d][1,3]$ dioxole-5-carbaldehyde (piperonal) and the complexes are formulated as $\left[(\text { diimine })_{2} \mathrm{Ru}(\mathrm{TSC})\right]\left(\mathrm{PF}_{6}\right)_{2}$ (where the TSC is the bidentate thiosemicarbazone ligand). The diimine in the complexes is either 2,2'-bipyridine or 1,10-phenanthroline. The complexes have been characterized by spectroscopic means (NMR, IR and UV-Vis) as well as by elemental analysis. We have studied the biophysical characteristics of the complexes by investigating their anti-oxidant ability as well as their ability to disrupt the function of the human topoisomerase II enzyme. The complexes are moderately strong binders of DNA with binding constants of $10^{4}$ $\mathrm{M}^{-1}$. They are also strong binders of human serum albumin having binding constants on the order of $10^{4} \mathrm{M}^{-1}$. The complexes show good in vitro anticancer activity against human colon cancer cells, Caco-2 and HCT-116 and indeed show some cytotoxic selectivity for cancer cells. The $\mathrm{IC}_{50}$ values range from $7-159 \mu \mathrm{M}$ (after $72 \mathrm{~h}$ drug incubation). They also have antibacterial activity against Gram-positive strains of pathogenic bacteria with $\mathrm{IC}_{50}$ values as low as $10 \mu \mathrm{M}$; little activity was seen against Gram-negative strains. It has been established that all the compounds are catalytic inhibitors of human topoisomerase II.
\end{abstract}

\section{Keywords}

Thiosemicarbazone; diimine; DNA; anticancer; human serum albumin; topoisomerase II

() 2011 Elsevier B.V. All rights reserved

*floyd.beckford@lyon.edu, Ph: (870) 307-7212; Fax: (870) 307-7496.

Publisher's Disclaimer: This is a PDF file of an unedited manuscript that has been accepted for publication. As a service to our customers we are providing this early version of the manuscript. The manuscript will undergo copyediting, typesetting, and review of the resulting proof before it is published in its final citable form. Please note that during the production process errors may be discovered which could affect the content, and all legal disclaimers that apply to the journal pertain. 


\section{Introduction}

Schiff bases are an important set of chelatin ligands in main group and transition metal coordination chemistry and have become an important class of compounds in medicinal and pharmaceutical fields as well [1-3]. Metal complexes of Schiff bases have been designed and synthesized to explore their pharmacological activity, for instance finding applications as model analogues of certain metallo-enzymes. One particular set of Schiff bases that has been studied very aggressively over the past decade is the thiosemicarbazones. Thiosemicarbazones are of considerable pharmacological interest since a number of derivatives have shown a broad spectrum of chemotherapeutic properties. The wide range of biological activities possessed by substituted thiosemicarbazones includes cytotoxic, antitumor [4], antibacterial [5], and antiviral [6] properties. The biological properties of the ligands can be modified and enhanced by linkage to metal ions [7-9].

Ruthenium complexes of diimine ligands such as 2,2'-bipyridine (bpy) and 1,10phenanthroline (phen) are widely used in bioinorganic chemistry particularly as probes for DNA. Some of these compounds also possess interesting anticancer properties and may be candidates for drugs [10-15]. While it is believed that DNA is a primary target for such complexes, since DNA replication is integral to the progression of these diseases, there is also the recognition that the observed biological activity is not always related to their DNAbinding ability. Consequently studies that seek to investigate other possible targets such as enzymes and other proteins are being undertaken [16-18]. The binding of drugs to plasma proteins is a fundamental factor, important in determining the overall pharmacological activity of the drug. Among the human serum proteins, albumin (HSA) acts as a reservoir for a long duration of action, and binding ultimately affects drug absorption, metabolism, distribution and excretion, properties that are of key importance to drug development. Since HSA serves as a transport carrier for drugs, it is important to study the interactions of potential drugs with this protein.

In this paper we report on a study of a family of mixed-ligand diimine ruthenium complexes of the type $\left[(\text { bipy })_{2} \mathrm{Ru}(\mathrm{TSC})\right]\left(\mathrm{PF}_{6}\right)_{2}$ and $\left[(\text { phen })_{2} \mathrm{Ru}(\mathrm{TSC})\right]\left(\mathrm{PF}_{6}\right)_{2}$ where TSC is a chelating thiosemicarbazone ligand derived from piperonal. We report on their biophysical reactivity (-interaction with DNA and human serum albumin), their cytotoxicity towards a number of human cancer cell lines and their antibacterial behavior towards a number of pathogenic and facultative bacteria. We also report their capability as antioxidants by investigating their reactivity with 2,2-diphenyl-1-picrylhydrazyl (dpph) radicals.

\section{Experimental Section}

\subsection{Materials and methods}

Analytical or reagent grade chemicals were used throughout. All the chemicals including solvents were obtained from Sigma-Aldrich (St. Louis, MO, USA) or other commercial vendors and used as received. The metal complexes were synthesized using a Discover SClass microwave reactor (CEM, Matthews, USA). Microanalyses (C, H, N) were performed by Desert Analytics, Tucson, USA. Proton and carbon nuclear magnetic resonance (NMR) spectra were recorded in dimethylsulfoxide- $d_{6}$ on a Varian Mercury $300 \mathrm{MHz}$ spectrometer operating at room temperature. The residual ${ }^{1} \mathrm{H}$ and ${ }^{13} \mathrm{C}$ present in DMSO- $d_{6}(2.50$ and $39.51 \mathrm{ppm}$ respectively) were used as internal references. Infrared (IR) spectra in the range $4000-500 \mathrm{~cm}^{-1}$ were obtained using the ATR accessory on a Nicolet 6700 FTIR spectrophotometer. The electronic spectra were recorded using quartz cuvettes on an Agilent 8453 spectrophotometer in the range $190-1100 \mathrm{~nm}$ using samples dissolved in DMSO. Fluorescence spectra were recorded on a Varian Cary Eclipse spectrophotometer. 


\subsubsection{Synthesis of compounds}

2.1.1.1 Ligands: The ligands, 2-(benzo $[d][1,3]$ dioxol-5-

ylmethylene)hydrazinecarbothioamide, (HpTSC), 2-(benzo[d][1,3]dioxol-5-ylmethylene)-Nmethylhydrazinecarbothioamide, (MepTSC), 2-(benzo[d][1,3]dioxol-5-ylmethylene)-Nethylhydrazinecarbothioamide, (EtpTSC) and 2-(benzo[ $d][1,3]$ dioxol-5-ylmethylene)-Nphenylhydrazinecarbothioamide (PhpTSC), were synthesized as follows: Equimolar amounts piperonal (benzo[ $d][1,3]$ dioxole-5-carbaldehyde) and the appropriate $\mathrm{N}(4)$ alkylsubstituted thiosemicarbazide were suspended in $80 \mathrm{~mL}$ of absolute anhydrous ethanol containing a few drops of glacial acetic acid. The reaction mixture was heated at reflux for $3-4 \mathrm{~h}$ and a pale yellow suspension resulted. The reaction mixture was cooled and filtered through a glass-sintered crucible. The pale yellow solid which was obtained was thoroughly washed with ethanol followed by ether and dried by suction.

pHTSC: Yield $80 \%$ of an off-white solid. Analysis - Calc for $\mathrm{C}_{9} \mathrm{H}_{9} \mathrm{~N}_{3} \mathrm{O}_{2} \mathrm{~S}: \mathrm{C}, 48.42 ; \mathrm{H}$, 4.06; N, 18.82. Found: C, 48.40; H, 4.02; N, 18.67. m.p. $189^{\circ} \mathrm{C}$. IR $\left(\mathrm{cm}^{-1}\right): v\left(\mathrm{NH}_{2}, \mathrm{NH}\right)$ $3427,3252,3153 ; v(\mathrm{C}=\mathrm{N}) 1592 ; v(\mathrm{C}=\mathrm{S}) 1260,838 .{ }^{1} \mathrm{H}$ NMR $\left(300.08 \mathrm{MHz}, \mathrm{DMSO}-\mathrm{d}_{6}\right): \delta$ $=6.04(2 \mathrm{H}, \mathrm{s}, \mathrm{H} 1), 7.63(1 \mathrm{H}, \mathrm{s}, \mathrm{H} 3), 7.04(1 \mathrm{H}, \mathrm{d} \mathrm{J}=8.4 \mathrm{~Hz}, \mathrm{H} 5), 6.89(1 \mathrm{H}, \mathrm{d} \mathrm{J}=7.8 \mathrm{~Hz}$, H6), $7.92(1 \mathrm{H}, \mathrm{s}, \mathrm{H} 8), 8.01\left(1 \mathrm{H}, \mathrm{s}, \mathrm{N}_{\mathrm{b}} \mathrm{H}\right), 8.04\left(1 \mathrm{H}, \mathrm{s}, \mathrm{N}_{\mathrm{b}} \mathrm{H}\right), 11.3\left(1 \mathrm{H}, \mathrm{s}, \mathrm{N}_{\mathrm{a}} \mathrm{H}\right) .{ }^{13} \mathrm{C}$ NMR (75.463 MHz, DMSO-d 6 ); $\delta=102.01$ (C1), 105.97 (C6), 108.81 (C3), 124.55 (C5), 129.42 (C4), 142.68 (C8), 148.70 (C2), 149.54 (C7), 178.30 (C9).

pMeTSC: Yield $96 \%$ of a pale-yellow solid. Analysis - Calc for $\mathrm{C}_{10} \mathrm{H}_{11} \mathrm{~N}_{3} \mathrm{O}_{2} \mathrm{~S}: \mathrm{C}, 50.62 ; \mathrm{H}$, 4.67; N, 17.71. Found: C, 50.62; H, 4.62; N, 17.50. m.p. $209^{\circ} \mathrm{C}$. IR $\left(\mathrm{cm}^{-1}\right): v\left(\mathrm{NH}_{2}, \mathrm{NH}\right)$ 3344,$3152 ; v(\mathrm{C}=\mathrm{N}) 1590 ; v(\mathrm{C}=\mathrm{S}) 1283,828 .{ }^{1} \mathrm{H}$ NMR $\left(300.08 \mathrm{MHz}, \mathrm{DMSO}-\mathrm{d}_{6}\right): \delta=6.07$ $(2 \mathrm{H}, \mathrm{s}, \mathrm{H} 1), 7.66(1 \mathrm{H}, \mathrm{s}, \mathrm{H} 3), 7.07(1 \mathrm{H}, \mathrm{d} \mathrm{J}=8.1 \mathrm{~Hz}, \mathrm{H} 5), 6.91(1 \mathrm{H}, \mathrm{d} \mathrm{J}=7.8 \mathrm{~Hz}, \mathrm{H} 6), 8.51$ $(1 \mathrm{H}, \mathrm{s}, \mathrm{H} 8), 7.94\left(1 \mathrm{H}, \mathrm{s}, \mathrm{N}_{\mathrm{b}} \mathrm{H}\right), 11.38\left(1 \mathrm{H}, \mathrm{s}, \mathrm{N}_{\mathrm{a}} \mathrm{H}\right), 3.00\left(3 \mathrm{H}, \mathrm{t}, \mathrm{N}_{\mathrm{b}}-\mathrm{CH}_{3}\right) .{ }^{13} \mathrm{C}$ NMR $(75.463$ $\left.\mathrm{MHz}, \mathrm{DMSO}-\mathrm{d}_{6}\right) ; \delta=30.78\left(\mathrm{~N}_{\mathrm{b}}-\mathrm{CH}_{3}\right), 101.47$ (C1), 105.15 (C6), 108.19 (C3), 123.76 (C5), 128.88 (C4), 141.38 (C8), 148.82 (C2), 148.06 (C7), 177.51 (C9).

pEtTSC: Yield 84\% of a pale-yellow solid. Analysis - Calc for $\mathrm{C}_{11} \mathrm{H}_{13} \mathrm{~N}_{3} \mathrm{O}_{2} \mathrm{~S}$ : C, 52.57; $\mathrm{H}$, 5.21; N, 16.72. Found: C, 52.66; H, 5.06; N, 16.58. m.p. $169^{\circ} \mathrm{C}$. IR $\left(\mathrm{cm}^{-1}\right): v\left(\mathrm{NH}_{2}, \mathrm{NH}\right)$ 3375,$3143 ; v(\mathrm{C}=\mathrm{N}) 1589 ; v(\mathrm{C}=\mathrm{S}) 1255,832 .{ }^{1} \mathrm{H}$ NMR $\left(300.08 \mathrm{MHz}, \mathrm{DMSO}-\mathrm{d}_{6}\right): \delta=6.07$ (2H, s, H1), $7.66(1 \mathrm{H}, \mathrm{s}, \mathrm{H} 3), 7.07(1 \mathrm{H}, \mathrm{d} \mathrm{J}=8.1 \mathrm{~Hz}, \mathrm{H} 5), 6.92(1 \mathrm{H}, \mathrm{d} \mathrm{J}=7.8 \mathrm{~Hz}, \mathrm{H6}), 8.56$ $(1 \mathrm{H}, \mathrm{s}, \mathrm{H} 8), 7.94\left(1 \mathrm{H}, \mathrm{s}, \mathrm{N}_{\mathrm{b}} \mathrm{H}\right), 11.32\left(1 \mathrm{H}, \mathrm{s}, \mathrm{N}_{\mathrm{a}} \mathrm{H}\right), 3.58\left(2 \mathrm{H}, \mathrm{q}, \mathrm{N}_{\mathrm{b}}-\mathrm{CH}_{2}\right), 1.14\left(3 \mathrm{H}, \mathrm{t}, \mathrm{N}_{\mathrm{b}^{-}}\right.$ $\left.\mathrm{CH}_{2}-\mathbf{C H}_{3}\right) .{ }^{13} \mathrm{C}$ NMR $\left(75.463 \mathrm{MHz}, \mathrm{DMSO}-\mathrm{d}_{6}\right) ; \delta=14.72\left(\mathrm{~N}_{\mathrm{b}}-\mathrm{CH}_{2}-\mathbf{C H}_{3}\right), 38.22\left(\mathrm{~N}_{\mathrm{b}}-\mathbf{C H}_{2}-\right.$ $\mathrm{CH}_{3}$ ), 101.47 (C1), 105.23 (C6), 108.19 (C3), 123.78 (C5), 128.84 (C4), 141.50 (C8), 148.83 (C2), 148.05 (C7), 176.46 (C9).

pPhTSC: Yield 94\% of a light-yellow solid. Analysis - Calc for $\mathrm{C}_{15} \mathrm{H}_{13} \mathrm{~N}_{3} \mathrm{O}_{2} \mathrm{~S}: \mathrm{C}, 60.18 ; \mathrm{H}$, 4.38; N, 14.04. Found: C, 60.21; H, 4.50; N, 13.95. m.p. $189^{\circ} \mathrm{C}$. IR $\left(\mathrm{cm}^{-1}\right): v\left(\mathrm{NH}_{2}, \mathrm{NH}\right)$ 3353,$3134 ; v(\mathrm{C}=\mathrm{N}) 1597 ; v(\mathrm{C}=\mathrm{S}) 1253,869 .{ }^{1} \mathrm{H}$ NMR $\left(300.08 \mathrm{MHz}, \mathrm{DMSO}-\mathrm{d}_{6}\right): \delta=6.08$ $(2 \mathrm{H}, \mathrm{s}, \mathrm{H} 1), 7.85(1 \mathrm{H}, \mathrm{s}, \mathrm{H} 3), 7.55(1 \mathrm{H}, \mathrm{d} \mathrm{J}=14 \mathrm{~Hz}, \mathrm{H} 5), 7.38(1 \mathrm{H}, \mathrm{d} \mathrm{J}=15 \mathrm{~Hz}, \mathrm{H6}), 8.07$ $(1 \mathrm{H}, \mathrm{s}, \mathrm{H} 8), 10.11\left(1 \mathrm{H}, \mathrm{s}, \mathrm{N}_{\mathrm{b}} \mathrm{H}\right), 11.74\left(1 \mathrm{H}, \mathrm{s}, \mathrm{N}_{\mathrm{a}} \mathrm{H}\right), 6.93-7.25\left(5 \mathrm{H}, \mathrm{m}, \mathrm{N}_{\mathrm{b}}-\mathrm{C}_{6} \mathrm{H}_{5}\right) .{ }^{13} \mathrm{C}$ NMR (75.463 MHz, DMSO-d 6 ); $\delta=101.50$ (C1), 105.67 (C6), 108.18 (C3), 142.67 (C8), 149.09 (C2), 148.10 (C7), 175.78 (C9). The phenyl carbons were located in a closely-spaced cluster between $120-130 \mathrm{ppm}$ that overlapped with the signals from the aromatic ring of the benzodioxole moiety.

2.1.1.2 Metal complexes: The starting ruthenium complexes, $\left[(\text { phen })_{2} \mathrm{RuCl}_{2}\right] \cdot \mathrm{H}_{2} \mathrm{O}$ and $\left[(\mathrm{bpy})_{2} \mathrm{RuCl}_{2}\right]$, were synthesized as described in the literature [19]. The target complexes were synthesized by the following general method: Equimolar amounts of [(phen $\left.)_{2} \mathrm{RuCl}_{2}\right]$ $\cdot \mathrm{H}_{2} \mathrm{O}$ or $\left[(\mathrm{bpy})_{2} \mathrm{RuCl}_{2}\right]$ and the appropriate ligand was suspended in $8-10 \mathrm{~mL}$ of ethylene 
glycol in a $35-\mathrm{mL}$ reaction vessel. The vessel was capped and the reaction mixture saturated with argon for 15 minutes. The reaction vessel was then placed in the microwave reactor and heated at $150{ }^{\circ} \mathrm{C}$ for 5 minutes (using a dynamic method). The dark brown suspension became a dark red solution. This solution was poured onto $5-10 \mathrm{~mL}$ of a saturated aqueous solution of $\mathrm{KPF}_{6}$ which resulted in the immediate precipitation of a red solid. The solid was collected by vacuum filtration, washed with water followed by ether and then dried at the vacuum pump. The product was recrystallized from dichloromethane/ether (1 and $\mathbf{2})$, ethanol/hexanes (3 and $\mathbf{4})$ or ethanol/ether (5).

[(bpy $\left.)_{2} \boldsymbol{R} \boldsymbol{u}(\boldsymbol{H p T S C})\right]\left(\boldsymbol{P F}_{\boldsymbol{6}}\right)_{2}: \mathbf{1}$. Red solid. Yield: $180 \mathrm{mg}$ (47\%). Analysis; Calc. for $\mathrm{C}_{29} \mathrm{H}_{25} \mathrm{~F}_{12} \mathrm{~N}_{7} \mathrm{O}_{2} \mathrm{P} 2 \mathrm{Ru}$ S: C, 37.59; H, 2.72; N, 10.58. Found: C, 37.84: H, 2.73; N, 10.75. IR $\left(\mathrm{cm}^{-1}\right): v\left(\mathrm{NH}_{2}, \mathrm{NH}\right) 3424(\mathrm{w}), 3373,3152(\mathrm{w}) ; v(\mathrm{C}=\mathrm{N}) 1620 ; v(\mathrm{~N}-\mathrm{N}) 1036 ; v(\mathrm{C}=\mathrm{S}) 1255$, 830; $\lambda_{\max }(\log \varepsilon) ; 294 \mathrm{~nm}(3.8) ; 430 \mathrm{~nm}$ (broad).

[(bpy $\left.)_{2} \boldsymbol{R} \boldsymbol{u}(\boldsymbol{E t p T S C})\right]\left(\boldsymbol{P F}_{\boldsymbol{6}}\right)_{2}: \mathbf{2}$. Red solid. Yield: $259 \mathrm{mg}(66 \%)$. Analysis; Calc. for $\mathrm{C}_{31} \mathrm{H}_{29} \mathrm{~F}_{12} \mathrm{~N}_{7} \mathrm{O}_{2} \mathrm{P} 2 \mathrm{Ru} \mathrm{S}$ : C, 39.00; H, 3.06; N, 10.26. Found: C, 39.29; H, 3.18; N, 10.18. IR $\left(\mathrm{cm}^{-1}\right): v\left(\mathrm{NH}_{2}, \mathrm{NH}\right) 3421(\mathrm{w}), 3113(\mathrm{w}, \mathrm{b}) ; v(\mathrm{C}=\mathrm{N}) 1586 ; v(\mathrm{~N}-\mathrm{N}) 1034 ; v(\mathrm{C}=\mathrm{S})$ 1247, $827 ; \lambda_{\max }(\log \varepsilon) ; 303 \mathrm{~nm}(3.8) ; 276 \mathrm{~nm}$ (broad).

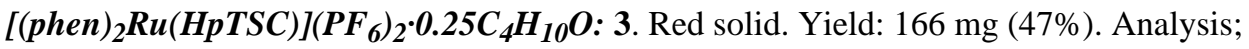
Calc. for $\mathrm{C}_{34} \mathrm{H}_{27.5} \mathrm{~F}_{12} \mathrm{~N}_{7} \mathrm{O}_{2.5} \mathrm{P}_{2} \mathrm{Ru} \mathrm{S}$ : C, 41.12; H, 2.79; N, 9.87. Found: C, 41.84; H, 2.42; $\mathrm{N}, 10.33$. IR $\left(\mathrm{cm}^{-1}\right): v\left(\mathrm{NH}_{2}, \mathrm{NH}\right) 3424,3373(\mathrm{w}), 3152(\mathrm{w}) ; v(\mathrm{C}=\mathrm{N}) 1620 ; v(\mathrm{~N}-\mathrm{N}) 1036 ; v$ $(\mathrm{C}=\mathrm{S}) 1251,830 ; \lambda_{\max }(\log \varepsilon) ; 300 \mathrm{~nm}(\mathrm{sh}) ; 430 \mathrm{~nm}$ (broad).

[(phen $)_{2} \boldsymbol{R u}(\text { MepTSC)](PF })_{2}$ : 4. Dark-red solid. Yield: $256 \mathrm{mg}$ (71\%). Analysis; Calc. for $\mathrm{C}_{34} \mathrm{H}_{27} \mathrm{~F}_{12} \mathrm{~N}_{7} \mathrm{O}_{2} \mathrm{P} 2 \mathrm{Ru}$ S: C, 41.30; H, 2.75; N, 9.92. Found: C, 42.20; H, 2.62; N, 10.19. IR $\left(\mathrm{cm}^{-1}: v\left(\mathrm{NH}_{2}, \mathrm{NH}\right) 3424(\mathrm{w}), 3337(\mathrm{w}) ; v(\mathrm{C}=\mathrm{N}) 1620 ; v(\mathrm{~N}-\mathrm{N}) 1036 ; v(\mathrm{C}=\mathrm{S}) 1256,833\right.$; $\lambda_{\max }(\log \varepsilon) ; 360 \mathrm{~nm}(\mathrm{sh}) ; 440 \mathrm{~nm}$ (broad).

[(phen $\left.)_{2} \boldsymbol{R u}(\boldsymbol{E t p T S C})\right]\left(\boldsymbol{P F}_{\boldsymbol{6}}\right)_{2}$ : 5. Dark-red solid. Yield: $286 \mathrm{mg}$ (71\%). Analysis; Calc. for $\mathrm{C}_{35} \mathrm{H}_{29} \mathrm{~F}_{12} \mathrm{~N}_{7} \mathrm{O}_{2} \mathrm{P}_{2} \mathrm{Ru} \mathrm{S}$ : C, 41.92; H, 2.92; N, 9.78. Found: C, 41.80; H, 2.68; N, 9.88. IR $\left(\mathrm{cm}^{-1}: v\left(\mathrm{NH}_{2}, \mathrm{NH}\right) 3420,3371(\mathrm{w}) ; v(\mathrm{C}=\mathrm{N}) 1574 ; v(\mathrm{~N}-\mathrm{N}) 1036 ; v(\mathrm{C}=\mathrm{S}) 826 ; \lambda_{\max }(\log \right.$ ع); $292 \mathrm{~nm}$ (3.8); $400 \mathrm{~nm}$ (broad).

\subsection{DNA-interaction studies}

All experiments involving interaction of the complexes with DNA were carried out in Tris buffer ( $5 \mathrm{mM}$ Tris, $50 \mathrm{mM} \mathrm{NaCl}, \mathrm{pH}$ 7.20). Stock solutions of ct-DNA were prepared by dissolving commercial nucleic acids in buffer and stored at $4{ }^{\circ} \mathrm{C}$ for more than $24 \mathrm{~h}$ to achieve homogeneity. After dilutions DNA concentration per nucleotide phosphate was determined spectrophotometrically using the molar absorption coefficient of $6600 \mathrm{M}^{-1} \mathrm{~cm}^{-1}$ at $260 \mathrm{~nm}$ [20]. A solution of ct-DNA in the buffer gave a ratio of UV absorbance at 260 and $280 \mathrm{~nm}$ of $\geq 1.8$ indicating that the DNA did not require purification [21]. The DNA stock solutions were stored at $-20^{\circ} \mathrm{C}$ and used within 1 week after their preparation. The doubly purified water used in all experiment was from a Milli-Q system.

2.2.1 Viscosity measurements-Viscosity studies were carried out using a CannonManning semi micro-dilution viscometer (type 75, Cannon Instruments Co., State College, PA, USA) immersed vertically in a thermostatted water bath maintained at $31 \pm 1{ }^{\circ} \mathrm{C}$. The viscosity of DNA solutions was measured in the presence and absence of the metal complexes. The DNA concentration was maintained at $10 \mu \mathrm{M}$, while the complex concentration varied from $0-60 \mu \mathrm{M}$. Data are presented as $\left(\eta / \eta_{0}\right)^{1 / 3}$ versus $1 / \mathrm{R}$, where $\mathrm{R}=$ $[\mathrm{DNA}] /\left[\right.$ complex] and $\eta$ is the viscosity of DNA in the presence of the complex and $\eta_{0}$ is the 
relative viscosity of DNA alone. Relative viscosity values were calculated from the observed flow times of DNA solution ( $\mathrm{t}$ ) corrected for the flow time of buffer alone $\left(\mathrm{t}_{0}\right)$, using the expression $\eta_{0}=\left(t-t_{0}\right) / t_{0}$. Flow time was measured with a digital stopwatch and each sample was measured three times and the average flow time was used.

2.2.2 Ethidium bromide displacement experiments-In the ethidium bromide (EB) displacement experiment, a 3-mL sample of a solution that was $10 \mu \mathrm{M}$ DNA and $0.33 \mu \mathrm{M}$ EB (saturated binding levels [22]), in Tris buffer was titrated with aliquots of a concentrated solution of a complex producing reaction mixtures with varied mole ratio of complex to ctDNA. After each addition the solution was vortex for 30 seconds and allowed to mix at the appropriate temperature for 5 minutes before measurement. The fluorescence spectrum of the solution was obtained by exciting at $520 \mathrm{~nm}$ and measuring the emission spectra from $540-700 \mathrm{~nm}$ using $5 \mathrm{~nm}$ slits.

2.2.3 Chemical nuclease activity-The DNA unwinding and cleavage ability of the complexes were evaluated by agarose gel electrophoresis of supercoiled pBR322 DNA. The experiments were done in the dark or after exposure to long-radiation UV light. Samples of pBR322 DNA $(0.1 \mu \mathrm{g} / \mu \mathrm{L})$ were incubated with the complexes (in concentrations ranging from 10 to $300 \mu \mathrm{M})$ in Tris buffer $(50 \mathrm{mM}$ Tris, $18 \mathrm{mM} \mathrm{NaCl}, \mathrm{pH}$ 8.2) at room temperature for $1 \mathrm{~h}$ in the dark or subjected to $365 \mathrm{~nm}$ light. The reactions were quenched by addition of $3 \mu \mathrm{L}$ of loading buffer ( $0.25 \%$ bromophenol blue and $15 \%$ Ficoll in water). Samples of the reaction mixtures were loaded onto a $1 \%$ agarose gel in TBE buffer $(89 \mathrm{mM}$ Tris, $89 \mathrm{mM}$ boric acid, $2 \mathrm{mM}$ EDTA, $\mathrm{pH} 8.2$ ). The gels were subjected to electrophoresis for $1 \mathrm{~h}$ at $70 \mathrm{~V}$, followed by staining with $0.5 \mu \mathrm{g} / \mathrm{mL}$ ethidium bromide for 30 minutes. The bands on the gel were visualized under UV light and photographed using a GEL Logic 440 Imaging System with a Kodak Molecular Imaging Software.

\subsection{Activity against topoisomerase II}

The capability of the ruthenium complexes to affect human topoisomerase II activity was analyzed using gel electrophoresis. The reaction mixture was a total of $20 \mu \mathrm{L}$ and Tris buffer (50 mM Tris, $18 \mathrm{mM} \mathrm{NaCl}, \mathrm{pH}$ 7.2) was used as the reaction buffer for the complexes. The "complete buffer" was made fresh daily by adding equal volumes of $10 \times$ Topo II Assay Buffer A (0.5 M Tris- $\mathrm{HCl}(\mathrm{pH} 8), 1.50 \mathrm{M} \mathrm{NaCl}, 100 \mathrm{mM} \mathrm{MgCl}_{2}, 5 \mathrm{mM}$ dithiothreitol and $300 \mu \mathrm{g} \mathrm{BSA} / \mathrm{mL}$ ) to the $10 \times$ ATP Buffer B (20 mM ATP in water) and was used at $1 / 5$ volume. The metal complexes were added from a $3 \mathrm{mM}$ stock solution made fresh in a 1:1 solution of DMSO and Tris buffer to yield varying concentrations $(20 \mu \mathrm{M}, 50 \mu \mathrm{M}, 100 \mu \mathrm{M}$, and $300 \mu \mathrm{M}$ ). Etoposide used as a control poison was added from a $10 \mathrm{mM}$ stock solution in DMSO to create a $1 \mathrm{mM}$ concentration in the reaction. Also a control lane, in which DMSO was added to DNA at the highest concentration it appears in a single reaction, was included. DNA (pHOT-1) was used at a concentration of $12.5 \mathrm{ng} / \mu \mathrm{l}$. Human topoisomerase II $\alpha$ (3 units, $1.5 \mu \mathrm{l}$ ) was added and the reactions were immediately transferred from the ice bath to a $37^{\circ} \mathrm{C}$ hot water bath for 30 minutes. The reactions were terminated by adding $1 / 10$ volume of $10 \%$ sodium dodecyl sulfate. Proteinase $\mathrm{K}$ was added at a concentration of $50 \mu \mathrm{g} / \mathrm{ml}$. The reactions were incubated in the hot water bath for an additional 15 minutes. 1/10 volume of $10 \times$ gel loading buffer was added and the reactions removed from the water bath. They were cleaned up via a CIA extraction. An equal volume of CIA (chloroform:isoamyl alcohol 24:1) was added, the mixture vortex and then briefly centrifuged. The upper blue layer was split in half and placed into corresponding wells of two $1 \%$ agarose gels in Tris-BorateEDTA buffer (TBE). The gels were run at $70 \mathrm{~V}$ for $2 \mathrm{~h}$ in TBE. One gel contained $0.2 \mu \mathrm{g} / \mathrm{ml}$ ethidium bromide. This EB gel was run with TBE containing $0.5 \mu \mathrm{g} / \mathrm{ml}$ ethidium bromide. This gel was then de-stained in DNA-free water for 30 minutes while the other gel was stained in an ethidium bromide/buffer solution for 30 minutes. It was then de-stained as 
mentioned before. The bands on the gel were imaged under UV light using a GEL Logic 440 Imaging System with Kodak Molecular Imaging Software.

\subsection{DPPH antioxidant assay}

The assay was conducted in a 96-well plate with a total volume of $250 \mu \mathrm{L}$ in each well. To various concentrations of the metal complex DPPH was added (to a final concentration of $150 \mu \mathrm{M}$ ) and the reactions incubated at $25^{\circ} \mathrm{C}$ for 30 minutes in the dark (shielded from light) before the absorbances were read at $520 \mathrm{~nm}$. Ascorbic acid (AA) was used as a comparison and a reagent blank along with a control were included on the plate. The control is a solution of DPPH and the reagent blank is a solution of the complex at the appropriate concentrations.

$$
\mathrm{SC} \%=\left\lceil\frac{\mathrm{A}_{\text {control }}-\mathrm{A}_{\text {sample }}}{\mathrm{A}_{\text {control }}}\right\rceil \times 100 \%
$$

$\mathrm{SC} \%$ is the scavenging capacity. $\mathrm{IC}_{50}$ values denote the concentration of metal complex required to scavenge $50 \%$ of the DPPH radicals and were obtained from a plot of SC $v s$. [metal complex]. $\mathrm{A}_{\text {control }}$ is the absorbance of the control and $\mathrm{A}_{\text {sample }}$ is the absorbance of the sample.

\subsection{Reaction with human serum albumin (HSA)}

For the fluorescence titration, a similar procedure to the EB displacement experiments was done. Solutions of HSA (fatty acid-free) were prepared in Tris buffer (50 mM Tris, $\mathrm{pH} 7.40$, $100 \mathrm{mM} \mathrm{NaCl}$ ) and stored in the dark at $4{ }^{\circ} \mathrm{C}$. The protein concentration was determined spectrophotometrically using the molar absorptivity of $36000 \mathrm{M}^{-1} \mathrm{~cm}^{-1}$ at $280 \mathrm{~nm}$ [23]. In the experiments, a $3.0-\mathrm{mL}$ solution of HSA $(5 \mu \mathrm{M})$ was placed in a quartz cuvette and titrated with various amounts of a concentrated solution of the complex producing solutions with varied mole ratios of complex to HSA. The complex concentration ranged from 3-30 $\mu \mathrm{M}$. The fluorescence spectra of the solutions were obtained by exciting at $295 \mathrm{~nm}$ and measuring the emission spectra from $300-500 \mathrm{~nm}$.

\subsection{Cell culture}

Cell lines included two human colon cancer cells: HCT-116 (human colon carcinoma) and Caco-2 (human epithelial colorectal adenocarcinoma). In addition, normal human colon cells CCD-18Co (human colon fibroblasts) were included. All cell lines were obtained from the American Type Culture Collection (ATCC, Rockville, MD, USA) and maintained at the University of Rhode Island. Caco-2 cells were grown in EMEM medium supplemented with $10 \% \mathrm{v} / \mathrm{v}$ fetal bovine serum, $1 \% \mathrm{v} / \mathrm{v}$ nonessential amino acids, $1 \% \mathrm{v} / \mathrm{v}$ L-glutamine and $1 \%$ $\mathrm{v} / \mathrm{v}$ antibiotic solution (Sigma). HCT-116 cells were grown in McCoy's 5a medium supplemented with $10 \% \mathrm{v} / \mathrm{v}$ fetal bovine serum, $1 \% \mathrm{v} / \mathrm{v}$ nonessential amino acids, $2 \% \mathrm{v} / \mathrm{v}$ HEPES and $1 \% \mathrm{v} / \mathrm{v}$ antibiotic solution. CCD-18Co cells were grown in EMEM medium supplemented with $10 \% \mathrm{v} / \mathrm{v}$ fetal bovine serum, $1 \% \mathrm{v} / \mathrm{v}$ nonessential amino acids, $1 \% \mathrm{v} / \mathrm{v} \mathrm{L}$ glutamine and $1 \% \mathrm{v} / \mathrm{v}$ antibiotic solution and were used from $\mathrm{PDL}=26$ to $\mathrm{PDL}=35$ for all experiments. Cells were maintained at $37{ }^{\circ} \mathrm{C}$ in an incubator under a $5 \% \mathrm{CO}_{2} / 95 \%$ air atmosphere at constant humidity and maintained in the linear phase of growth. The $\mathrm{pH}$ of the culture medium was determined using $\mathrm{pH}$ indicator paper ( $\mathrm{pHydrion}{ }^{\mathrm{TM}}$ Brilliant, $\mathrm{pH} 5.5-$ 9.0, Micro Essential Laboratory, NY, USA) inside the incubator. All of the test samples were solubilized in DMSO ( $<0.5 \%$ in the culture medium) by sonication and were filter sterilized $(0.2 \mu \mathrm{m})$ prior to addition to the culture media. Control cells were also run in parallel and subjected to the same changes in medium with a $0.5 \%$ DMSO. 
2.6.1 Cytotoxicity assay-The assay was carried out as described previously [24] to measure the $\mathrm{IC}_{50}$ values for samples. Briefly, the in vitro cytotoxicity of samples were assessed in tumor cells by a tetrazolium-based colorimetric assay, which takes advantage of the metabolic conversion of MTS [3-(4,5-dimethylthiazol-2-yl)-5-(3-

carboxymethoxyphenyl)-2-(4-sulfenyl)- $2 H$-tetrazolium, inner salt] to a reduced form that absorbs light at $490 \mathrm{~nm}$. Cells were counted using a hemacytometer and were plated at 2,000 $-5,000$ cells per well, depending on the cell line, in a 96-well format for $24 \mathrm{~h}$ prior to drug addition. Test samples and a positive control, etoposide $(4 \mathrm{mg} / \mathrm{mL})$, were solubilized in DMSO by sonication. All samples were diluted with media to the desired treatment concentration and the final DMSO concentration per well did not exceed $0.5 \%$. Control wells were also included on all plates. Following a $24 \mathrm{~h}, 48 \mathrm{~h}$ or $72 \mathrm{~h}$ drug-incubation period at $37{ }^{\circ} \mathrm{C}$ with serially diluted test compounds, MTS, in combination with the electron coupling agent, phenazine methosulfate, was added to the wells and cells were incubated at $37^{\circ} \mathrm{C}$ in a humidified incubator for $3 \mathrm{~h}$. Absorbance at $490 \mathrm{~nm}\left(\mathrm{OD}_{490}\right)$ was monitored with a spectrophotometer (SpectraMax M2, Molecular Devices Corp., operated by SoftmaxPro v. 4.6 software, Sunnyvale, CA, USA) to obtain the number of surviving cells relative to control populations. The results are expressed as the median cytotoxic concentrations $\left(\mathrm{IC}_{50}\right.$ values) and were calculated from six-point dose response curves using 4-fold serial dilutions. Each point on the curve was tested in triplicate. Data are expressed as mean $\pm \mathrm{SE}$ for three replicates on each cell line.

\subsection{Antimicrobial assay}

The in vitro antimicrobial activity of the complexes was investigated as the minimum inhibitory concentration (MIC) against a number of Gram-positive (Staphylococcus aureus, Bacillus cereus, Enterococcus faecalis) and Gram-negative (Escherichia coli, Pseudomonas aeruginosa, Salmonella typhimurium) bacteria strains. The bacteria were maintained on nutrient agar and cultured in Mueller Hinton Broth and compounds were dissolved in DMSO. The MIC was determined from a microdilution method. Approximately $30 \mathrm{~mL}$ of bacteria culture were incubated overnight at $37.0^{\circ} \mathrm{C}$ to produce exponentially growing cells. This was then diluted to yield a suspension containing $1.5 \times 10^{8} \mathrm{CFU} / \mathrm{mL}$ (based on comparison of the turbidity to a $0.5 \mathrm{McF}$ arland standard). Subsequently, $250 \mu \mathrm{L}$ of this bacteria mixture were inoculated into a sterile 96 -well microplate. Various amounts of the compounds were added to wells to give predetermined concentrations ranging from $2-50$ $\mu \mathrm{M}$. The well absorbances (at $600 \mathrm{~nm}$ ) were recorded on a BioTek Synergy HT microplate reader immediately after inoculation. The microplates were incubated for $24 \mathrm{~h}$ at $37.0^{\circ} \mathrm{C}$, and then the absorbance recorded again after the $24 \mathrm{~h}$ period. The MIC was defined as the lowest concentration of compound that did not produce any visible cell-growth or change in absorbance after incubation. Solvent, media and positive growth controls were included on each plate. Ampicillin or streptomycin was used as a standard comparison. Each plate contained three replicates of each concentration and two separate experiments were done.

\section{Results and Discussion}

The ligands were synthesized using a general method involving the acid-catalyzed condensation of piperonal with the corresponding $\mathrm{N}$-alkyl substituted thiosemicarbazide in ethanol. The complexes were made using a microwave-assisted thermal reaction of the dichlorobis(diimine)ruthenium(II) starting material with the ligands. [ $\left.\mathrm{Ru}(\text { diimine })_{2} \mathrm{Cl}_{2}\right]$ and ligand were suspended in the ethylene glycol solvent and the reaction mixture saturated with argon. The mixture was then heated using a dynamic method that was developed as follows: time $=5 \mathrm{~min}$; temperature $=150{ }^{\circ} \mathrm{C} ;$ power $=$ variable; stirring $=\max ;$ cooling $=$ on. The reaction produced red solids that are insoluble in alcohols and water but are very soluble in 
acetone, $\mathrm{CH}_{2} \mathrm{Cl}_{2}$ and DMSO. From microanalytical and spectroscopic data we propose that the complexes can be formulated as $\left[(\text { diimine })_{2} \mathrm{Ru}(\mathrm{TSC})\right]\left(\mathrm{PF}_{6}\right)_{2}$ (Fig. 1).

\subsection{Nuclear magnetic resonance}

A simple comparison of the NMR spectra of the ligands and the metal complexes reveals the presence of the azomethinic proton signal in the spectra of the complexes which is indicative of the non-deprotonation of the ligand confirming the neutrality of the coordinated thiosemicarbazone. In all the complexes there is a general upfield shift of nearly $1-1.5$ ppm, which reflects coordination through the azomethine nitrogen. We have previously noted this behavior for similar complexes [25]. The signal ascribed to the aminic proton in the free ligands along with that for the aldehydic proton is buried under the multiplet of peaks between 6 and $9 \mathrm{ppm}$ that is associated with the diimine group but we have seen for similar complexes that the aminic proton generally move downfield by as much as $0.5 \mathrm{ppm}$. This is indicative of the binding of the thiocarbonyl group and is the result of a decrease in the electron density caused by electron withdrawal by the metal ions from the thione sulfur. The protons associated with the 1,3-dioxole fragment do not shift and show up at approximately $6.00 \mathrm{ppm}$ for all the complexes. The other proton signals show up at their expected positions.

\subsection{Infrared spectra}

Thiosemicarbazones exhibit characteristic bands corresponding to various functional groups in specific energy regions. Thiosemicarbazone ligands can coordinate in a number of different ways. Most commonly they bind as either of two tautomeric forms - a neutral thione form or the anion from the thiol form. Infrared spectrophotometry can be used to identify the coordinated form and it was observed that the characteristic absorption peaks of all complexes are similar. The absence of a $\mathrm{n}(\mathrm{S}-\mathrm{H})$ absorption in the region 2600-2500 $\mathrm{cm}^{-1}$ is considered as evidence that the thione form of the ligands exist in the solid state $[26,27]$. There are two or three weak and broad bands in the $\mathrm{n}(\mathrm{N}-\mathrm{H})$ region $(3450-3150$ $\mathrm{cm}^{-1}$ ) and these signals play an important role in evaluating the nature of the bonding in thiosemicarbazone complexes. The presence of these bands supports the thione formulation of the ligand in the complexes and they do not shift significantly on complexation. The coordination sites can also be inferred from the spectral bands attributed to the $\mathrm{C}=\mathrm{N}$ iminic and $\mathrm{C}=\mathrm{S}$ thioamide IV groups. The ligands show a medium intensity band at $1570-1620$ $\mathrm{cm}^{-1}$ that we ascribe to $\mathrm{C}=\mathrm{N}$ and these are shifted slightly to higher or lower energy upon complexation. The bands in the free ligand attributed to the $\mathrm{C}=\mathrm{S}$ group shifts to lower frequencies by $4-27 \mathrm{~cm}^{-1}$. The size of the shifts suggest that the ligand coordinates as a neutral, bidentate (through the azomethine nitrogen and thiocarbonyl sulfur) ligand in all the complexes. The presence of the azomethinic hydrogen in all the complexes indicates the lack of thiolate formation.

\subsection{Interaction with DNA}

3.3.1 Ethidium bromide competition experiment-The complexes do not have a peak with strong enough absorption spectrophotometry. So we have investigated the reaction of the complexes with calf thymus DNA via a fluorescence competition experiment. Ethidium bromide (EB) is a well-known dye that is commonly used as a marker for nucleic acids by intercalating between the base pairs and generating a fluorescent adduct. The fluorescence from the adduct may be quenched by addition of a compound that can displace the EB from the binding sites on the DNA [25]. This quenching may be taken as evidence that the compound can bind to DNA likely in a similar fashion to EB. Using $\mathbf{2}$ as a typical example, (also see Supplemental Information - S1), we can see from Figure 2 that the complex can indeed reduce the fluorescence of the EB-DNA solution. A quantitative 
estimate of this quenching behavior may be obtained by treating the data according to the Stern-Volmer equation (1):

$$
\frac{F_{0}}{F}=1+K_{S V}[R u]=1+K_{q} \tau_{0}[R u]
$$

In this equation $\mathrm{F}_{0}$ and $\mathrm{F}$ are the fluorescence intensities of the reaction solution in the absence and presence of the metal compound. $\mathrm{K}_{\mathrm{SV}}$ is the Stern-Volmer quenching constant which is the measure of the effectiveness of the complex as a quencher. Figure 3 shows the Stern-Volmer plots and the excellent linearity of the plots confirms the quenching behavior. The values of the quenching constant, seen in Table 1 , range from $1.6 \times 10^{4}$ to $4 \times 104 \mathrm{M}^{-1}$ indicating that these are only moderate quenchers. In general, the complexes with the phen unit are stronger quenchers than the bpy complexes. This might implicate an intercalative mode (albeit weak) of binding. To assess the strength of the binding, equation 2 was employed to calculate the apparent binding constant.

$$
K_{a p p}=\frac{K_{E B}[E B]}{[R u]_{50 \%}}
$$

In this equation $\mathrm{K}_{\mathrm{EB}}$ is the binding constant for ethidium bromide, taken as $1.2 \times 10^{6} \mathrm{M}^{-1}$ [28] and $[\mathrm{Ru}]_{50 \%}$ is the concentration of the complex that causes a $50 \%$ reduction of the initial fluorescence. These values are shown in Table 1 and are on the order of $10^{4} \mathrm{M}^{-1}$ which again suggest that the complexes are moderate binders.

The quenching of the fluorescence can occur by two common mechanisms - dynamic and/or static quenching. We propose that in the reactions here the quenching is predominantly static. In such a scenario a quencher-fluorophore complex is formed. This is inferred from the bimolecular quenching constant $\left(\mathrm{K}_{\mathrm{q}}\right.$ in equation 1) calculated by using $\tau_{0}=22 \mathrm{~ns}$ [29] for the EB-DNA complex. $\mathrm{K}_{\mathrm{q}}$ for the reactions are on the order of $10^{12} \mathrm{M}^{-1} \mathrm{~s}^{-1}$ which is two orders of magnitude larger than the limiting value of $10^{10} \mathrm{M}^{-1} \mathrm{~s}^{-1}$ [30] considered the largest possible value in aqueous solution.

3.3.3 Viscometric studies-We have studied the interaction of the complexes with DNA by viscometry. This method is the most definitive way to verify if a small molecule can bind to DNA via an intercalative mechanism. The classical DNA intercalators will lengthen the strands resulting in an increase in the viscosity of the DNA solutions. On the other hand, complexes that bind exclusively in the DNA grooves by a partial or non-classical intercalation of the compound, (under the same conditions), can reduce its effective length, and consequently, its viscosity by bending the DNA helix [31]. The viscometric data, presented as a plot of $\left(\eta / \eta_{0}\right)^{1 / 3} v s$. the binding ratio [Ru]/[DNA], is shown in Figure 4. It was observed for the complexes that the viscosity of the DNA solutions did not change significantly over the studied range of metal concentrations. There is an overall slight decrease in viscosity (with the exception of $\mathbf{3}$ which showed inconsistent changes). This would suggest that the complexes can possibly interact with DNA via partial intercalation or groove binding. It is well known that $\left[\mathrm{Ru}(\mathrm{bpy})_{3}\right]^{2+}$ interacts with DNA strictly via electrostatic interactions and since our complexes are charged, this mode of interaction is also a possibility. Given the electronic nature of the piperonal sub-structure, major intercalation into DNA by this moiety seems improbable. So the viscometry results support the idea that if the complexes intercalate into DNA, the interaction is weak. 
3.3.4 Chemical nuclease activity-The chemical nuclease activity of complexes has been assessed by their ability to convert supercoiled pBR322 DNA from Form I to Form II by agarose gel electrophoresis in the dark as well as with UV irradiation under aerobic conditions. When circular plasmid DNA is probed by electrophoresis, relatively fast migration is normally observed for the intact supercoil form (Form I). If scission occurs on one strand (nicking), the supercoil will relax to generate a slower-moving open circular form (Form II). Figure 5, (see also Supplemental Information - S2), shows the electrophoretic separation of the DNA after incubation with 1 in the dark and after irradiation. In general it is clear that the complexes show some cleavage of the DNA and there is also a slight increase in this activity as the concentration of the complexes is increased (up to $300 \mu \mathrm{M}$ ). The extent of the cleavage is more pronounced when the reaction mixtures are irradiated with UV light $(365 \mathrm{~nm})$. There are no apparent differences in the cleavage ability of the complexes. This would suggest that the mechanism of cleavage is similar among the complexes.

3.3.5 Anti-topoisomerase activity-Though DNA is implicated as the main target for anticancer ruthenium compounds, affecting the activity of topo II may also be an effective mode of anti-neoplastic activity. Type II topoisomerases (topo II) are a class of ubiquitous enzymes that modulate the topological problems associated with DNA replication, transcription, and other nuclear processes by introducing temporary single- or double-strand breaks in the DNA. Topo II is a major enzyme in neoplastic cells. Consequently topoisomerases have been one of the major molecular targets in anticancer drug development. The ability of the complexes to affect the catalytic activity of human topoisomerases II was studied by a DNA relaxation assay. Supercoiled plasmid DNA was treated with topo II in the presence of varying concentrations of the complex and the products were analyzed by gel electrophoresis on agarose gel. Depending on the nature of the products one can propose if the complex is a poison or an inhibitor. Topo II-targeting agents control the topo II activity either by poisoning the enzyme or by inhibiting the enzyme. Topo II poisons act by increasing the concentration of covalent enzyme-cleaved DNA complexes. Catalytic inhibitors prevent topo II from carrying out its required physiological functions. In our experiments (see Supplemental Information - S3) enzyme activity is characterized by conversion of pHOT1 DNA from the supercoiled conformation (SC, Form I, Lane 1) to the fully relaxed conformation (R, Form II; see lanes 2 and 3). The species migrating between the two forms are the various topoisomers. Careful examination of the electrophorograms suggests that the complexes can inhibit the relaxation of the enzyme at high concentrations as evidenced by the reduction in the number of the topoisomers but a fully relaxed conformation is not observed. So we propose that the complexes can act as catalytic inhibitors of topo II.

\subsection{Antioxidant behavior}

Based on the data from experiments that show that the complexes can bind to DNA and further that there is strong activity regarding the cleavage of pBR322 plasmid DNA, we investigated the antioxidant properties of the complexes by using the 2,2-diphenyl-1picrylhydrazyl (dpph) radical method. The model of the scavenging of dpph radicals is a simple, rapid and convenient method that is extensively used to evaluate the antioxidant properties of compounds. The dpph radicals are stable but in the presence of compounds capable of donating hydrogen atoms the radical property is destroyed resulting in a color change from purple to yellow. In our experiments we used ascorbic acid as a standard comparison. It was observed that the complexes can indeed reduce the concentration of the initial dpph radicals in solution and this is taken as evidence of their antioxidant capabilities. All the compounds have similar $\mathrm{IC}_{50}$ values of $232 \mu \mathrm{M}, 235 \mu \mathrm{M}, 221 \mu \mathrm{M}$ and $265 \mu \mathrm{M}$ for $\mathbf{2}$, $\mathbf{3}, \mathbf{4}$ and $\mathbf{5}$ respectively. Under our reaction conditions ascorbic acid has an $\mathrm{IC}_{50}$ of $82 \mu \mathrm{M}$ 
suggesting that our compounds are about three times less effective as the well-known antioxidant under the reaction conditions. We can speculate that the cleavage of plasmid DNA by the complexes may not involve the generation of radical species.

\subsection{Reaction of the complexes with HSA}

Human serum albumin (HSA) is the most abundant blood serum protein, occurring to the extent of $0.63 \mathrm{mM}$. The protein serves as a transport unit for a wide variety of endogenous substances including drugs. In this study we investigated the binding of the complexes to HSA using fluorescence spectroscopy. HSA has a well-known structure that contains a single tryptophan residue that is responsible for the majority of the intrinsic fluorescence of the protein. On excitation at $295 \mathrm{~nm}$ HSA has strong fluorescence emission at $350 \mathrm{~nm}$. This emission can be attenuated by a small molecule binding at or near the tryptophan as this amino acid unit is quite susceptible to changes in its environment. As a representative example, Figure 6 shows that addition of $\mathbf{2}$ to HSA can very efficiently reduce the fluorescence so we can conclude that the complexes in general can bind to HSA. We can obtain a quantitative estimate of the strength of this binding by treating the data in an analogous manner to the EB-DNA competition experiments. That is, we can use the SternVolmer equation (Equation 1). Treatment of the data in this manner resulted in the plots shown in Figure 7. It was observed that the plots were not linear as predicted from the equation but showed significant positive deviations from linearity at higher concentration of added metal complexes. There are two common explanations for this deviation. First the HSA fluorescence can be quenched via both of the common quenching mechanisms operating simultaneously. For proteins the quenching constants are approximately the same $[32,33]$. Alternatively, there may be more than one independent binding site on the HSA and they are not all equivalently accessible to the complexes. Under these circumstances, the binding constant for the reaction can be obtained from a modified Stern-Volmer (MSV) analysis [34]. This involves treating the data using equation 3 :

$$
\frac{F_{0}}{F_{0}-F}=\frac{1}{f K[R u]}+\frac{1}{f}
$$

Here $f=$ fraction of the fluorophore that is initially accessible to the complex. This may be interpreted as the number of binding sites on the protein. $\mathrm{K}$ is the effective quenching constant for the fluorophore which can be taken as a binding constant assuming the decrease in fluorescence comes from the interaction of the HSA with the complexes. Figure 8 shows the plot of $\mathrm{F}_{0} / \mathrm{F}_{0}-\mathrm{F} v s .1 /[\mathrm{Ru}]$ from which we obtain $\mathrm{K}$ from the ratio of the intercept to the slope. The derived binding constants are between $10^{4}$ and $10^{5} \mathrm{M}^{-1}$ (Table 2) indicating that they are strong binders. The average number of binding sites as measured by $f$ was determined to be about 1.3. This number does not conclusively settle the question as to whether there is a single binding site on the protein.

\subsection{Cytotoxicity assay}

The in vitro cytotoxicity of the complexes $\mathbf{1 - 5}$ against two human cancer cell lines, HCT-116 (colon carcinoma) and Caco-2 (epithelial colorectal adenocarcinoma) and a noncancerous cell line, CCD-18Co (colon fibroblasts) was investigated using a tetrazoliumbased (MTS) colorimetric assay. Etoposide, a potent anti-neoplastic drug, was used as a standard comparison treatment. The $\mathrm{IC}_{50}$ values (Table 3 ), the median cytotoxic concentrations, were determined after 24,48 and $72 \mathrm{~h}$ of drug exposure. Generally, the longer the exposure time the more cytotoxic is the complexes with the $72 \mathrm{~h}$ exposure being between 1.2 and 2 times more effective compared to the $24 \mathrm{~h}$ exposure. As another generality, the Caco- 2 cell line is slightly more sensitive to the complexes than the HCT-116 
cell line. For instance at $72 \mathrm{~h}$ exposure, $\mathbf{1}$ is 1.3 times as cytotoxic against the Caco-2 line. We can speculate that the alkyl substituent on the thiosemicarbazone ligand is probably not very critical. 4, which contain a methyl substituent on $\mathrm{N} 3$, is the most cytotoxic with $\mathrm{IC}_{50}$ of 8.6 and $6.6 \mu \mathrm{M}$ at $72 \mathrm{~h}$ exposure against HCT-116 and Caco-2 respectively. These values are $2-2.5$ times as cytotoxic, under our assay conditions, as the comparison drug etoposide. With the bpy complexes, the un-substituted $(\mathrm{H})$ complex $(\mathbf{1})$ is more active than the ethylsubstituted analog. On the other hand, for the phen complexes the ethyl-substituted complex is more active. So we cannot draw any definitive conclusions as to any effect that the diimine or the thiosemicarbazone substituent have on the cytotoxic behavior. An interesting point to note is that all the complexes are less cytotoxic to the normal cells CCD18-Co indicating a definite cytotoxic selectivity towards cancer cells. In the best case for $\mathbf{4}$ for example, the compound is 17 times less cytotoxic to the normal cells. This effect is even more pronounced than for the standard drug treatment with etoposide being only about $\sim 2.5$ times more lethal to the cancer cells versus the non-cancerous cells.

The $\mathrm{IC}_{50}$ values for the complexes (Table 3) are in the range $7-159 \mu \mathrm{M}$ after incubation for $72 \mathrm{~h}$, indicating the good to poor cytotoxicity profiles of the complexes. Under the experimental conditions $\mathbf{1}$ and $\mathbf{4}$ show comparable or better activity to etoposide against both HCT-116 and Caco-2. In general however the complexes do not reach the activity of the standard against the cancer cell lines. This is in itself not an unusual issue. It is known that some ruthenium complexes have low in vitro toxicity but show good in vivo characteristics. For example, complexes of the type $[(\operatorname{arene}) \mathrm{Ru}(\mathrm{PTA}) \mathrm{Cl}]^{+}$exhibited low activity against cancer cells but had very good anti-metastatic activity in vivo [34].

\subsection{Antibacterial assay}

The in vitro antimicrobial efficiency of the complexes against a number of Gram-positive and Gram-negative bacteria has been determined as the minimum inhibitory concentrations. The compounds were tested at low concentrations due to solubility issues and to avoid excessive concentrations of the solvent DMSO in the wells. The complexes generally were more active against the Gram-positive bacteria than the Gram-negative species. Complex 1 showed no inhibition against the four bacteria strains used: Bacillus cereus, Staphylococcus aureus, Salmonella typhimurium or Escherichia coli. In addition $\mathbf{4}$ and $\mathbf{5}$ showed no inhibition against $B$. cereus and $S$. aureus. Complex $\mathbf{2}$ showed very good activity against both $B$. cereus and $S$. aureus with a MIC of $10 \mu \mathrm{M}$ but it showed no inhibition against $S$. typhimurium or E.coli 3 had an MIC of $20 \mu \mathrm{M}$ against B. cereus, $30 \mu \mathrm{M}$ against $S$. aureus and $50 \mu \mathrm{M}$ against $E$. coli. It did not show any activity against $S$. typhimurium. It should be pointed out that no inhibition is relative only to the highest concentration $(50 \mu \mathrm{M})$ of complex that we used. We have studied the antibacterial activity of the free ligands as well and in general the complexes were more active than the free ligands which showed no measureable activity at the concentrations studied. This is not unusual as it is known that complexation to a metal ion may induce improved biological activity [35] and in some cases even different biological activity. Such complexation could enhance the lipophilic character of the compound which favors its permeation through the lipid layers of cell membrane.

\section{Conclusion}

The complexes can bind to DNA in a nonspecific manner but the cytotoxic activity is not definitively related to the strength of the binding. So we cannot rule out that the interaction with DNA may contribute to the anticancer activity. We have also determined that human topoisomerase II is a plausible molecular target for ruthenium complexes and we are actively exploring this possibility in our laboratories. Since the complexes are strong binders of human serum albumin, we are also investigating other model proteins to identify other potential mechanisms for the anticancer activity of our ruthenium compounds. 


\section{Supplementary Material}

Refer to Web version on PubMed Central for supplementary material.

\section{Acknowledgments}

The project described was supported by Award Number P20RR16460 from the National Centre for Research Resources to FAB. The content is solely the responsibility of the authors and does not necessarily represent official views of the National Centre for Research Resources or the National Institutes of Health.

\section{References}

[1]. Sinha D, Tiwari AK, Singh S, Shukla G, Mishra P, Chandra H, Mishra AK. Eur. J. Med. Chem. 2008; 43:160-165. [PubMed: 17532543]

[2]. Karthikeyan MS, Prasad D, Poojary B, Bhat KS, Holla BS, Kumari NS. Bioorg. Med. Chem. 2006; 14:7482-7489. [PubMed: 16879972]

[3]. Adsule S, Barve V, Chen D, Ahmed F, Ping Dou Q, Padhye S, Sarkar FH. J. Med. Chem. 2006; 49:7242-7246. [PubMed: 17125278]

[4]. Quiroga AG, Perez JM, Lopez-Solera I, Masaguer JR, Luque A, Raman P, Edwards A, Alonso C, Navarro-Ranninger C. J. Med. Chem. 1998; 41:1399-1408. [PubMed: 9554873]

[5]. Offiong OE, Martelli S. Farmaco. 1994; 49:513-518. [PubMed: 7945719]

[6]. Hadjipavlou-Litina D. Pharmazie. 1996; 51:468-470. [PubMed: 8774839]

[7]. Garcia-Tojal J, Garcia-Orad A, Serra JL, Pizarro JL, Lezamma L, Arriortua MI, Rojo T. J. Inorg. Biochem. 1999; 75:45-54. [PubMed: 10402676]

[8]. Petering DH. Bioinorg. Chem. 1972; 1:255-271.

[9]. West DX, Liberta AE, Padhye SB, Chikate RC, Sonawane PB, Kumbhar AS, Yerande RG. Coord. Chem. Rev. 1993; 123:49-71.

[10]. Erkkila KE, Odom DT, Barton JK. Chem. Rev. 1999; 99:2777-2796. [PubMed: 11749500]

[11]. Liu J, Zhen WJ, Shi S, Tan CP, Chen JC, Zheng KC, Ji LN. J. Inorg. Biochem. 2008; 102:193202. [PubMed: 17825915]

[12]. Schatzschneider U, Niesel J, Ott I, Gust R, Alborzinia H, Wölfl S. ChemMedchem. 2008; 3:1104-1109. [PubMed: 18425738]

[13]. Liu YJ, Zeng CH, Huang HL, He LX, Wu FH. Eur. J. Med. Chem. 2010; 45:564-571. [PubMed: 19932529]

[14]. Liu J, Zheng WJ, Shi S, Tan CP, Chen JC, Zheng KC, Ji LN. J. Inorg. Biochem. 2008; 102:193202. [PubMed: 17825915]

[15]. Tan CP, Liu J, Chen LM, Shi S, Ji LN. J. Inorg. Biochem. 2008; 102:347-358. [PubMed: 18022241]

[16]. Gao F, Chao H, Wang JQ, Yuan YX, Sun B, Wei YF, Peng B, Ji LN. J. Biol. Inorg. Chem. 2007; 12:1015-1027. [PubMed: 17659367]

[17]. Gao F, Chao H, Zhou F, Chen X, Wei YF, Ji LN. J. Inorg. Biochem. 2008; 102:1050-1059. [PubMed: 18295337]

[18]. Gao F, Chen X, Wang JQ, Chen Y, Chao H, Ji LN. Inorg. Chem. 2009; 48:5599-5601. [PubMed: 19505113]

[19]. Sullivan BP, Salmon DJ, Meyer TJ. Inorg. Chem. 1978; 17:3334-3341.

[20]. Reichmann ME, Rice SA, Thomas CA, Doty PJ. J. Am. Chem. Soc. 1954; 76:3047-3053.

[21]. Vijayalakshmi R, Kanthimathi M, Subramanian V, Nair BU. Biochim. Biophys. Acta. 2000; 1475:157-162. [PubMed: 10832030]

[22]. Barton JK, Goldberg JM, Kumar CV, Turro NJ. J. Am. Chem. Soc. 1986; 108:2081-2088.

[23]. Krimm S, Bandekar J. Adv. Protein Chem. 1986; 38:181-364. [PubMed: 3541539]

[24]. Cory AH, Owen TC, Barltrop JA, Cory JG. Cancer Commun. 1991; 3:207-212. [PubMed: 1867954] 
[25]. Beckford FA, Shaloski M Jr. Leblanc G, Thessing J, Lewis-Alleyne LC, Holder AA, Li L, Seeram NP. Dalton Trans. 2009:10757-10764. [PubMed: 20023905]

[26]. Mostafa MM, El-Hammid A, Shallaby M, El-Asmay AA. Transition Met. Chem. 1981; 6:303305.

[27]. West DX, Liberta AE, Padhye SB, Chikate RC, Sonawane PB, Kumbha AS, Yerande RG. Coord. Chem.Rev. 1993; 123:49-71.

[28]. Peberdy JP, Malina J, Khalid S, Haman MJ, Rodger A. J. Inorg. Biochem. 2007; 101:1937-1945. [PubMed: 17719088]

[29]. Ghosh KS, Sahoo BK, Jana D, Dasgupta S. J. Inorg. Biochem. 2008; 102:1711-1718. [PubMed: 18541305]

[30]. Lacowicz, JR. Principles of Fluorescence Spectroscopy. 3rd Ed.. Springer; New York: 2006.

[31]. Long EC, Barton JK. Acc. Chem. Res. 1990; 23:271-273.

[32]. Eftnik R, Ghiron CA. J. Phy. Chem. 1976; 80:486-493.

[33]. Eftnik R, Ghiron CA. Anal. Biochem. 1981; 44:199-227.

[34]. Scolaro C, Bergamo A, Brescacin L, Delfino R, Cocchietto M, Laurenczy G, Geldbach TJ, Sava G, Dyson PJ. J Med Chem. 2005; 48:4161-4171. [PubMed: 15943488]

[35]. Lobana TS, Sharma R, Bawa G, Khanna S. Coord. Chem. Rev. 2008; 253:977-1055. 
<smiles>PN[As]=S</smiles><smiles>CC(C)NN=Cc1ccc2c(c1)OCO2</smiles>

$\mathrm{R}=\mathrm{H}, \mathrm{CH}_{3}, \mathrm{C}_{2} \mathrm{H}_{5}, \mathrm{C}_{6} \mathrm{H}_{5}$
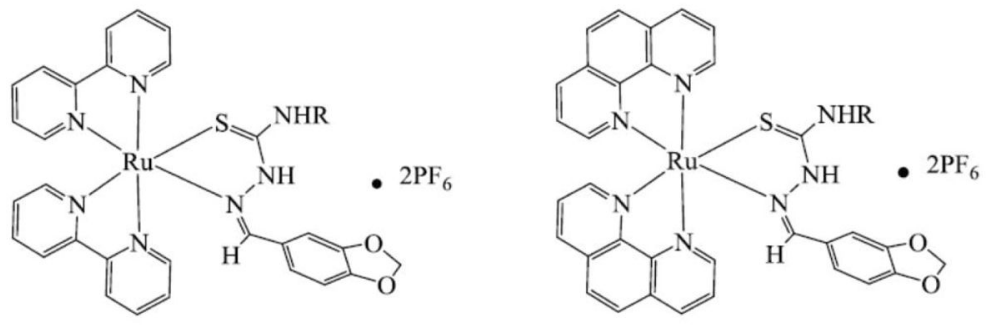

$\mathrm{R}=\mathrm{H}(\mathbf{1}) ; \mathrm{R}=\mathrm{C}_{2} \mathrm{H}_{5}(\mathbf{2})$

$\mathrm{R}=\mathrm{H}(\mathbf{3}) ; \mathrm{R}=\mathrm{CH}_{3}(4) ; \mathrm{R}=\mathrm{C}_{2} \mathrm{H}_{5}(\mathbf{5})$

Fig. 1.

Structure of the ligands and complexes synthesized in the study. 


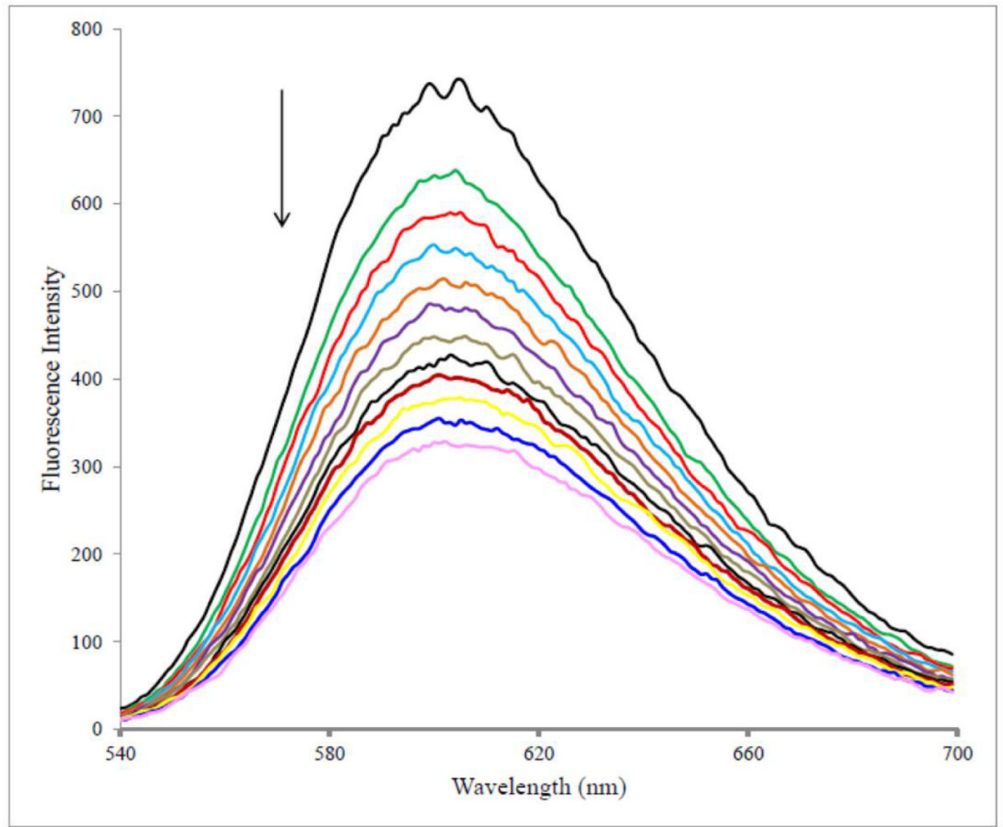

Fig. 2.

Fluorescence spectra of the EB-DNA complex in the absence and presence of increasing amounts of $2,1_{\mathrm{ex}}=520 \mathrm{~nm},[\mathrm{~EB}]=0.33 \mathrm{mM}$, [DNA] $=10 \mathrm{mM}$, [2] (inM): $0-60$ in $5 \mathrm{inM}$ increments. Temperature $=303 \mathrm{~K}$. 


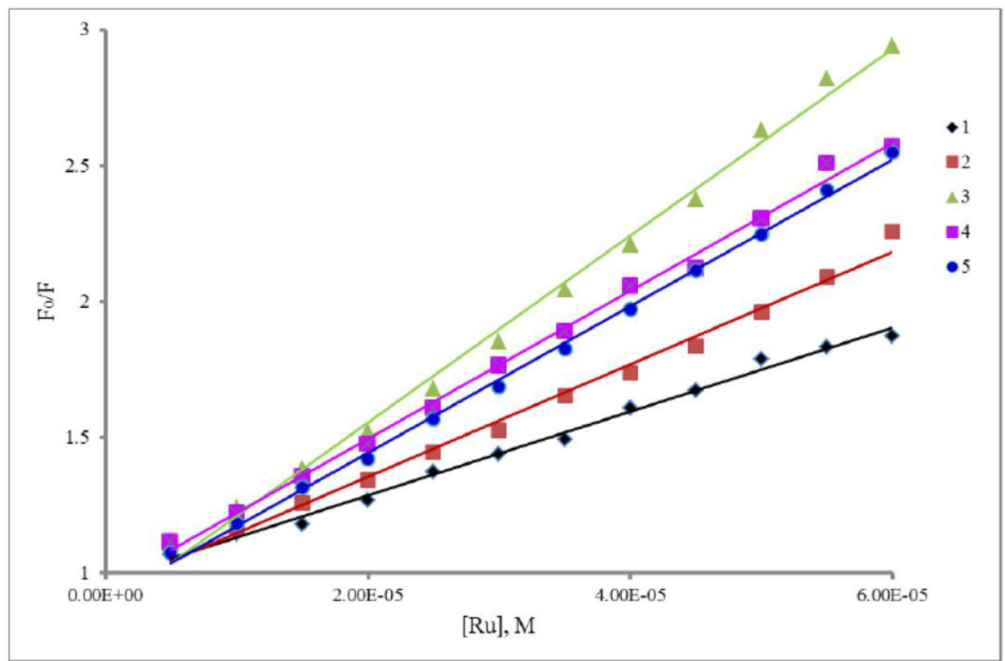

Fig. 3.

Stem-Volmer plots for the reaction of the complexes with EB-DNA at $308 \mathrm{~K}$. 


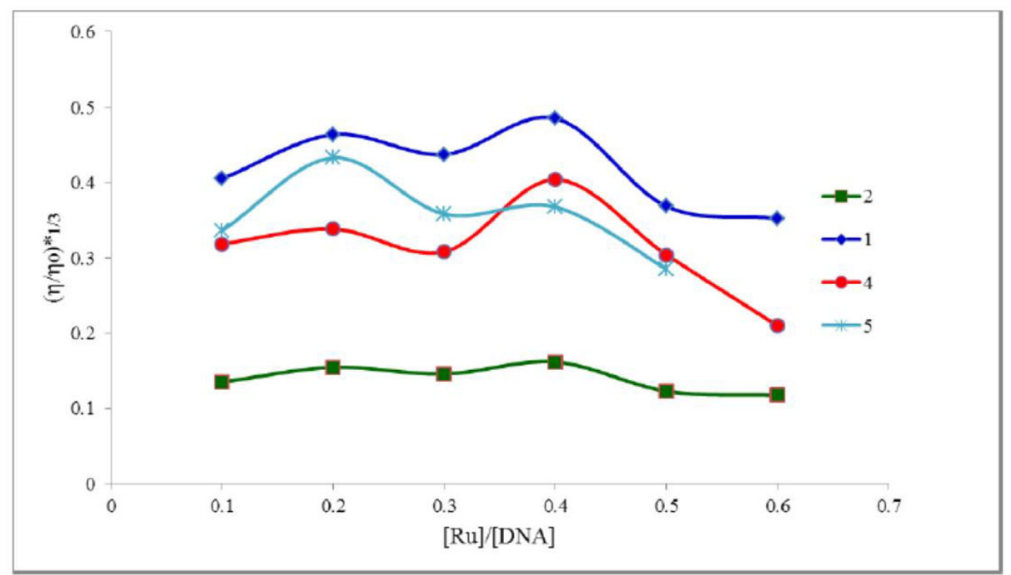

Fig. 4.

Effect of increasing concentrations of complexes $\mathbf{1}, \mathbf{2}, \mathbf{4}$ and $\mathbf{5}$ on the relative viscosity of ctDNA solutions at $304 \mathrm{~K} \pm 1 \mathrm{~K}$. 
A

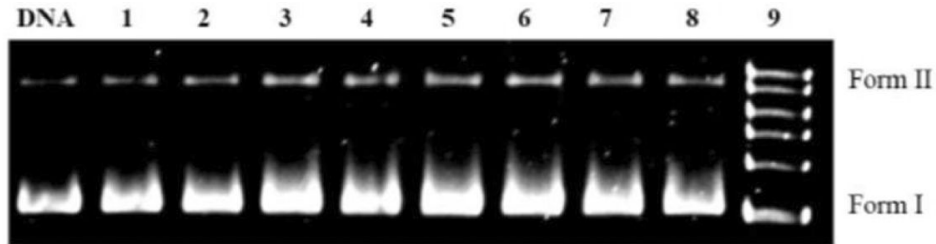

B

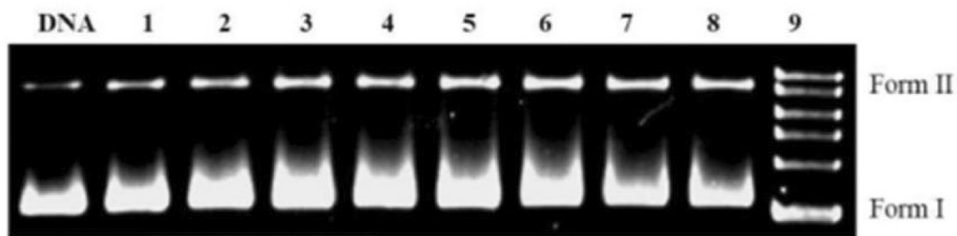

Fig. 5.

Agarose gel electrophoresis diagram for the cleavage of pBR322 DNA by 1 at ambient temperature in the dark (A) and upon irradiation with $365 \mathrm{~nm}$ light (B) under aerobic conditions. Irradiation time was $1 \mathrm{~h}$ and incubation time was $1 \mathrm{~h}$. Lane DNA, DNA alone; Lane 1 -8, DNA + 10, 20, 30,40, 50,100, 200 and 300 mM 1; Lane 10, DNA ladder 


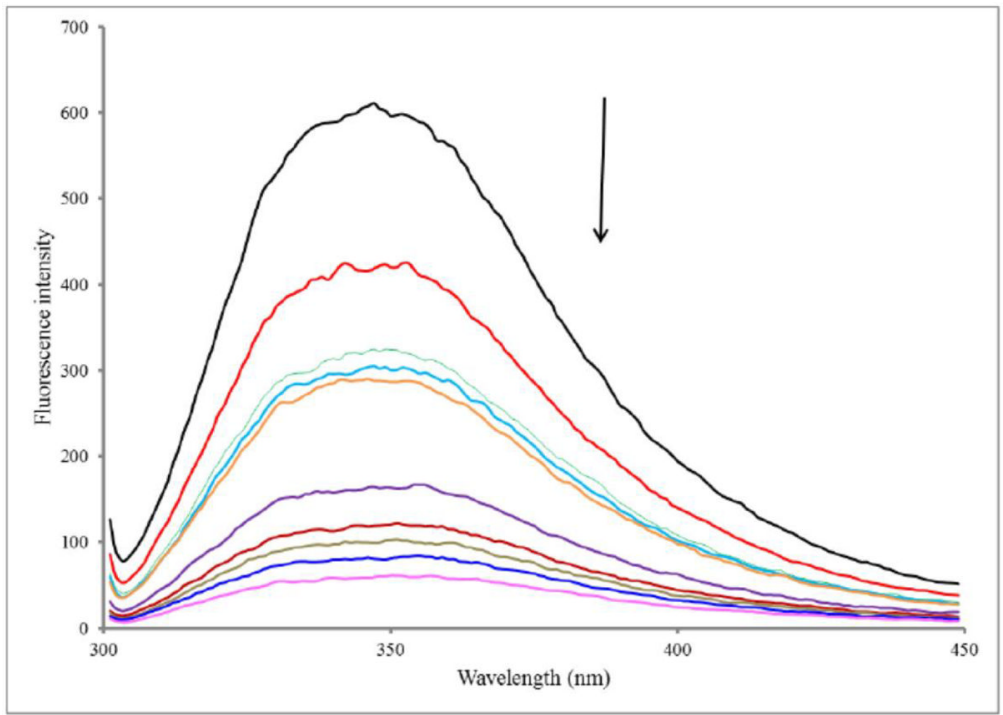

Fig. 6.

Emission spectra of HSA in the absence and presence of increasing amounts of 2, $1_{\mathrm{ex}}=295$ $\mathrm{nm},[\mathrm{HSA}]=5.0$ nil and [2] $(\mathrm{mM}): 0-35$ in $2.5 \mathrm{mM}$ increments. Temperature $=303.0 \mathrm{~K}$. 


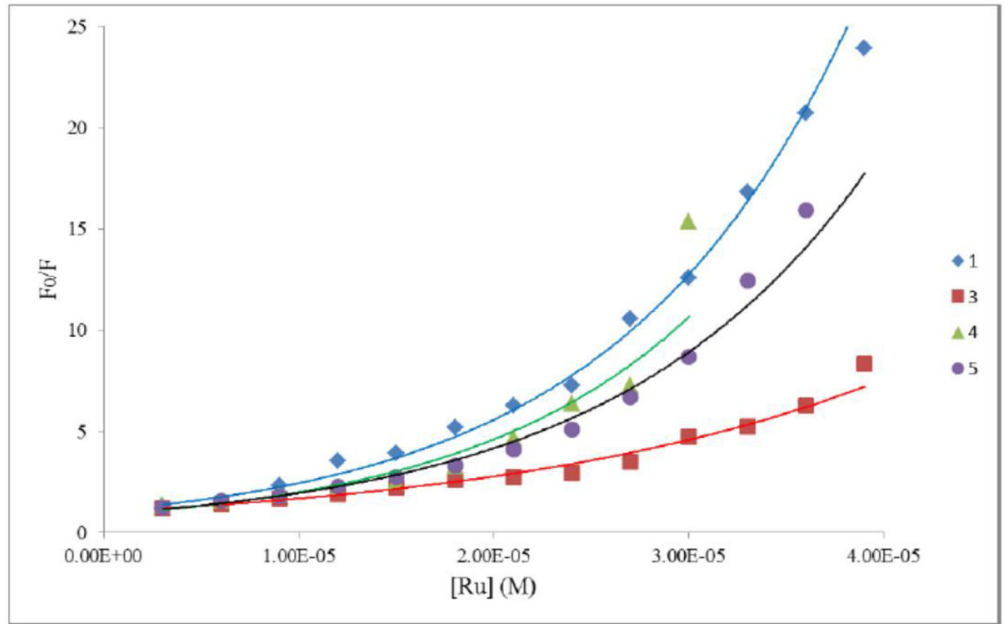

Fig. 7.

Stem-Volmer plots for the reaction of the complexes with HSA at $308 \mathrm{~K}$. 


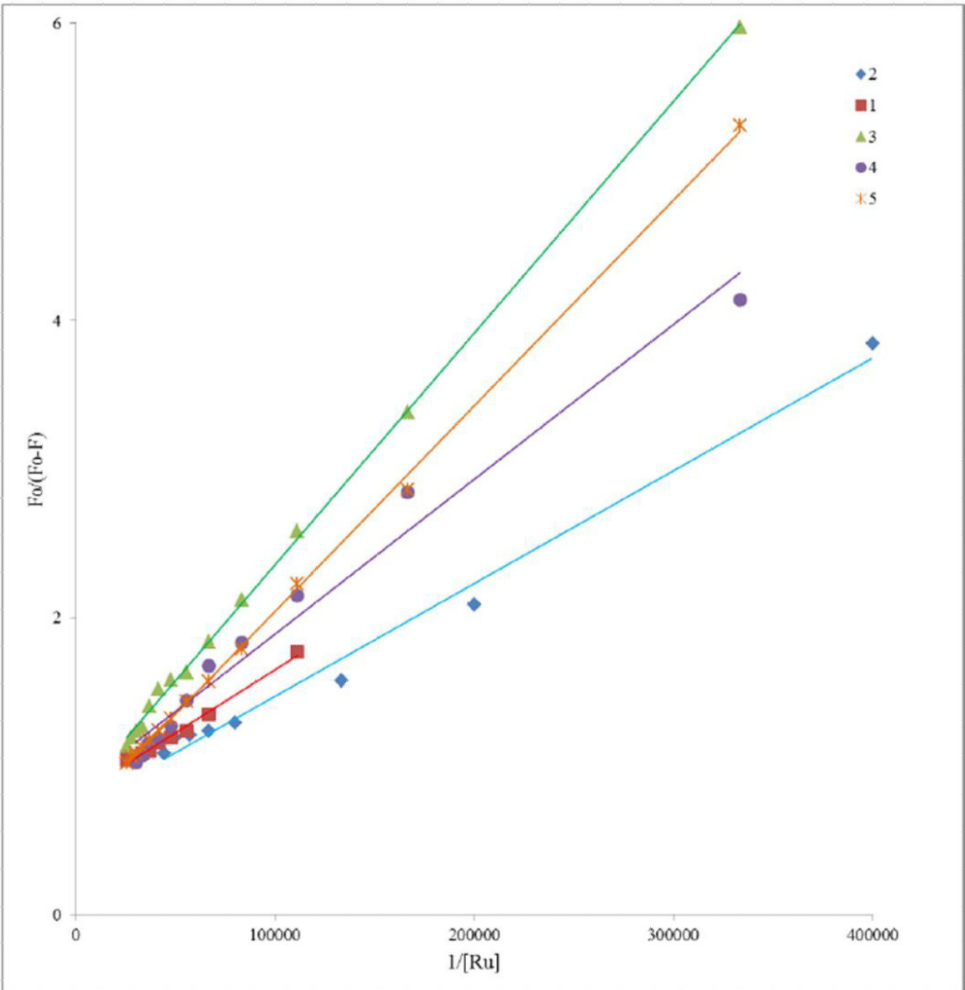

Fig. 8.

Plot of the modified Stern-Volmer equation: $\mathrm{F}_{0} /\left(\mathrm{F}_{0}-\mathrm{F}\right)$ vs. $1 /[\mathrm{Ru}]$, for the reaction of the complexes with HSA. 


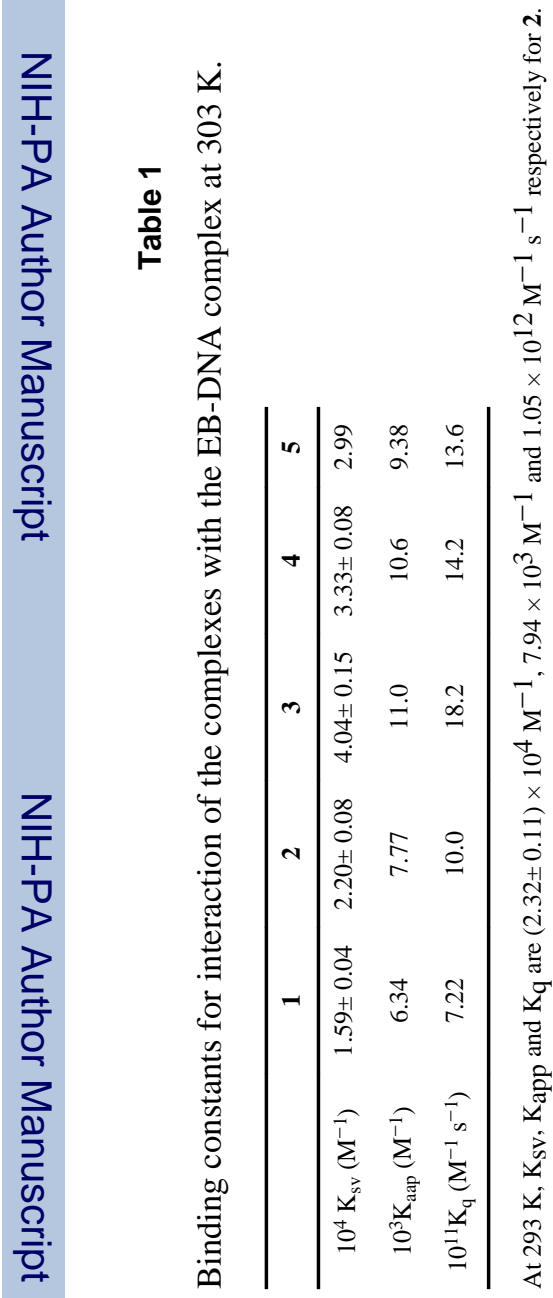




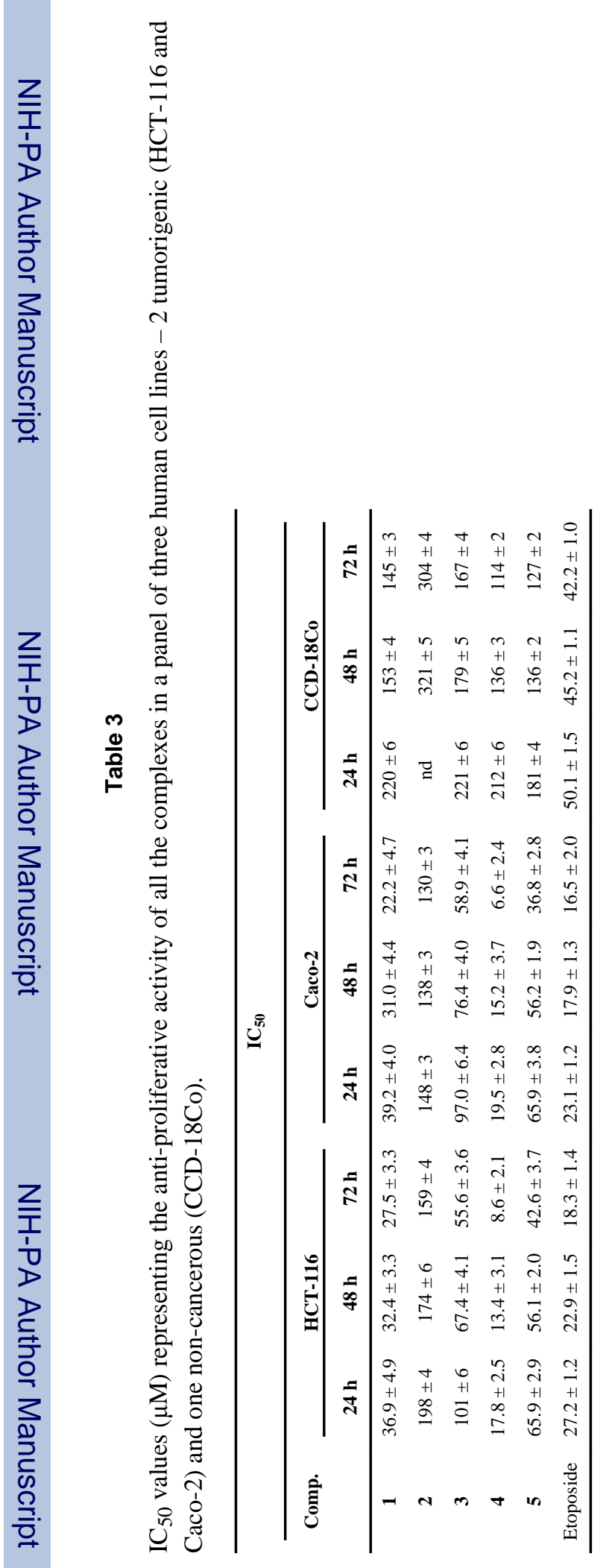

